\title{
Local Government Capacity in Post-Soviet Central Asia
}

\section{Rustamjon Urinboyev}

\author{
University of Lund, Sweden
}

cross $^{\text {ref }}$ http://dx.doi.org/10.5755/j01.ppaa.14.3.13431

\begin{abstract}
This paper explores the context, problems, quality, and challenges of local governance in four Central Asian countries: Kazakhstan, Kyrgyzstan, Tajikistan, and Uzbekistan. The prime focus is on the question of whether local governments in this region perform their functions in an effective and efficient way. It looks at the four conditions - contextual, structural, institutional and human resource conditions - as factors for explaining the capacity of local governments in the region. These questions will be investigated with reference to academic literature and policy papers on the topic. The findings indicate that local governments in Central Asia do not have real capacity to adequately address the needs and concerns of citizens, as they are heavily dependent on the central government in all policy issues, be it taxation, service delivery, local development, or privatization. The study suggests that local government reform in this region is not simply a matter of introducing Westernstyle governance structures or granting more autonomy to local actors. It is, more importantly, about understanding local socio-political context and promoting socioeconomic change.
\end{abstract}

Keywords: local government; Central Asia; public administration; decentralization; governance; post-Soviet societies; civil service reform.

Raktažodžiai: vietos valdžia, Vidurio Azija, viešasis administravimas, decentralizacija, valdymas, posovietinès visuomenès, valstybès tarnybos reforma.

\section{Introduction}

This paper aims to explore the context, problems, quality, and trajectories of local governance in four Central Asian countries: Kazakhstan, Kyrgyzstan, Tajikistan, and Uzbekistan ${ }^{1}$. More specifically, it tries to address the following two questions: (a) what local governments are supposed to do, and whether they do this in an adequate and efficient way, e.g. adequate service delivery in a varying area of policy areas; (b) how local governments do it, with regard to principles of good governance, e.g.

\footnotetext{
${ }^{1}$ This paper covers only four Central Asian countries - Kazakhstan, Kyrgyzstan, Tajikistan and Uzbekistan. Turkmenistan has not been included in this study due to scarcity of data.
} 
transparency, accountability, rule of law, voice and democratic and accountable government, the involvement of communities and community organizations. In doing so, the paper looks at the four conditions - contextual, structural, institutional and human resource conditions - as factors that can account for the capacity of local governments in the region.

The rest of the paper proceeds as follows: In part two, I will describe the conditions under which local government function in Central Asia, focusing on their service responsibilities, financial situation, internal structure and human resource conditions. This will help us discern the varying contexts in which local governments function in the region. Part three discusses the actual service delivery capacity of local governments and presents the main trends and challenges local governments face in the region. Part four draws out the implications of the study for scholarly debates on local government reform, and highlights the most important findings of the study.

\section{The Conditions under which Local Government Function in Central Asia}

This section covers the following two issues: (a) the actual tasks and responsibilities of local governments in Central Asia; (b) the conditions under which local government function in the region. First, I describe the national differences and commonalities with regard to history, socio-economic indicators, administrative culture, service delivery, and human resource conditions. Second, I present the internal structure of local governments in order to explain the position of local government vis-a-vis the central government.

\section{National Differences and Commonalities}

Unlike Europe, where the European Charter of Local Self-government provides a unifying governance structure for all the member of the Council of Europe [see e.g. 19], there is no such unifying embodiment of decentralization principles in Central Asia that provides venue for local government representatives and policy-makers to exchange knowledge and good practices at a regional level $[33]^{2}$. However, one can argue that the unifying governance structure for Central Asian countries is probably the existence of similar administrative culture and institutions that they all inherited from the Soviet Union. Notably, Central Asian countries did not exist in their present form as independent nation-states before they were incorporated into the Russian empire during the late nineteenth century [26]. Three Uzbek khanates (the Khiva

2 There is only one soft-law instrument - the Model Legal Act of the Interparliamentary Assembly of CIS Countries on Common Principles of Local Self-government Organization (24 November 1995) - that provides some sort of unifying governance structure for postSoviet countries. But this document has virtually no effect on local governance trajectories in the region, merely having a symbolical value. 
Khanate, the Kokand Khanate, and the Bukharan emirate) controlled most of the territory of contemporary Kazakhstan, Kyrgyzstan, Tajikistan, Turkmenistan, and Uzbekistan (ibid.). However, khans (rulers) had a limited power to control and mold the behavior of regional leaders $[23 ; 24 ; 49 ; 55 ; 56 ; 84 ; 91]$. Most of the contemporary forms of territorial power relations (i.e. central-local government relations) had been developed during the Soviet era. Hence, Central Asian countries share the following common characteristics:

- Resilience of the Soviet administrative traditions [e.g. 73; 71];

- Authoritarianism and centralization of power in the center [e.g. 62];

- Clientelistic culture, collectivism, and substantial influence of clans and elites, based on family, kinship, and business relationships, on policy processes and decisions [e.g. 93; 20; 85; 57; 58; 92; 98; 103; 104; 105; 106];

- Islamic public administration legacy $[32 ; 41 ; 27 ; 28 ; 51 ; 107]$;

- They are unitary states and have a multi-level administrative system in which the provinces (oblast, viloyat) include smaller districts (raions, nohiya), which in turn districts consist of rural and urban settlements, and the largest cities have the status of province or district [86];

- The central government appoints the heads of local governments and the governors (akims, hokims, hyakims) serve as representatives of the president and central government and heads of regional executive bodies.

Considering the existence of so many similarities one might assume that local government structures and conditions in Central Asia would not differ significantly, but this is not the case. As will be shown below, in post-Soviet period each Central Asian country has designed its local governance reforms independently, reckoning with its local socio-political context, economic conditions, history, culture, and administrative traditions.

The first line of division is the wealth and socio-economic indicators of the countries. Kazakhstan has the highest GDP per capita in the region, largely due to its abundant mineral resources [92]. Turkmenistan, possessing enormous gas resources, also has relatively high GDP per capita [92]. Uzbekistan, with its fairly industrialized economy and mineral resources, has better socio-economic indicators than the two poorest countries of the region, Kyrgyzstan and Tajikistan [57]. When discussing the capacity of local governments in Central Asia, one may also look at the Human Development Index (HDI) of the United Nations (UNDP 2014), which provides important data about the level and quality of education, health and living standards in the region. The country with the highest HDI-scores in the region is Kazakhstan (0.757), followed by Turkmenistan (0.698) and Uzbekistan (0.661). Kyrgyzstan (0.628) and Tajikistan (0.607) have the lowest HDI indicators in the region. This index is useful tool for explaining and comparing the service delivery capacity of local governments in the region.

We can also observe certain differences when it comes to civil service reform trajectories. Kazakhstan is the only country in the region that adopted Western style 
professional civil service system (Kazakh Civil Service Law, 2000), dividing civil servants into political and administrative employees [31]. Kyrgyzstan and Tajikistan also adopted laws on Civil Service but they do not make any distinction between political and administrative civil service positions [3; 47]. Uzbekistan's case is peculiar as it does not have a law on civil servants; instead, the public service system and the status of government employees are regulated by the Labor Code $[11 ; 34 ; 1]$. In theory, local government employees in all four Central Asian countries must be hired on a meritocratic basis through the open competition, considering such qualification requirements as education, work experience, knowledge of state and foreign languages, and knowledge of laws. Civil servants are evaluated periodically, every three to five years. Each country has a National Academy of Public Administration, which is responsible for establishing the national standards for civil service and carries out advanced training of personnel for public administration.

\section{Main Responsibilities of Local Governments}

The tasks decentralized to local governments in Central Asian countries include environmental protection, prevention of natural and technological accidents, fire protection, public sanitation, public order and security, local economic and social development, culture, tourism, sports, maintenance of leisure facilities, communal services (e.g. water, gas, electricity, heat supply, waste management, sewerage, engineering infrastructures), construction, maintenance and repair of local roads, public transport, support of employment and job creation, and development of small and medium enterprises. In Kazakhstan, Kyrgyzstan and Tajikistan, local governments are responsible mainly for providing social assistance to the needy families. Most of the social protection programs (e.g. pensions, unemployment benefits, maternity benefits, veterans, child benefits) are primarily financed by the state budget and administered by the territorial divisions of the state agencies responsible for social protection $[3 ; 47 ; 64 ; 37]$. Uzbekistan is a special case in this regard as the community-based organizations, mahallas have been charged with the administration and targeting of state social welfare benefits, such as child benefits, maternity benefits, and social assistance to the low-income families, families with children under sixteen and single mothers with children under two $[22 ; 11 ; 74]$. Funding for these programs is established centrally as part of consolidated budget expenditures, which in turn is transferred to the mahalla committees [ibid.]. The rest of social protection programs (e.g. pensions, benefits to veterans of the war) are the responsibility of district/city level units of the Ministry of Labor and Social Protection [11].

In Kazakhstan and Tajikistan, local governments are responsible for financing and provision of health care services and the central government finances only national public health programs, e.g. the centralized purchase of vaccines, preventing and mitigating dangerous infections, collecting the supply of blood and sanitary and epidemiological monitoring [64; 76]. In Uzbekistan and Kyrgyzstan, health care services are primarily financed by the central budget and administered by territorial 
structures of respective ministry. The local government is merely responsible for the maintenance and renovation of health care institutions [3; 11]. For instance, in Uzbekistan, central government takes care of health care services through regional, district and city level health care management bodies of the Ministry of Health, while in Kyrgyzstan, medical service providers receive funding from the state and the mandatory medical insurance fund and medical institutions are compensated in proportion to the number of people that they serve. There is a growing tendency towards privatization of health care services, particularly in Kazakhstan and partly in Kyrgyzstan and Tajikistan. For example, most health care services in Kazakhstan are provided by private medical institutions [64]. Special case in this respect is Uzbekistan where almost all health care services are provided by public authorities.

Countries also vary in relation to financing and administration of basic education. Local governments are primarily responsible for financing school education in Kazakhstan and Tajikistan [47; 64], whereas in Kyrgyzstan and Uzbekistan the schooling is a joint responsibility of the central and local government in the sense that the local educational departments of the Ministry of Education pays teachers' wages and oversees administrative control and other expenditures such as school maintenance are covered by the local budget $[3 ; 11]$.

\section{The Internal Structure of Local Government}

All Central Asian countries have inherited similar local government system from the Soviet Union, which consists of a local state administration (administrative body) and an elected local council (legislative body) at provincial (oblast) and district (raion) level [40]. The period for which the appointment/election is valid varies between four (Kazakhstan, Kyrgyzstan) and five (Uzbekistan, Tajikistan) years. The local administration represents the state executive and regulatory body at the oblast, raion or city levels and implements policies of the president and central government in provinces. The heads of local state administrations are all appointed by the central government, subject to [symbolical] approval of the corresponding councils $[3 ; 11$; 47; 64]. More specifically, in Kazakhstan and Uzbekistan, the president appoints regional (oblast-level) governors; oblast governors in turn appoint governors in districts and cities of oblast subordination [11; 64]. District and city governors are accountable to the regional governor, who in turn is accountable to the president [ibid.]. However, in Kyrgyzstan and Tajikistan, the president has the authority to appoint and dismiss the governors of regions, districts and towns, thus making both district and region-level governors directly accountable to the president $[3 ; 2]$. Hence, local governors (e.g. district-level governors) often experience double or even triple subordination, being accountable to the president, central government and regional governor.

Local councils, running alongside local administrations, are main local 'legislative' bodies, which are elected by the inhabitants of the respective administrative-territorial unit through general, equal and direct vote $[3 ; 11 ; 47 ; 64]$. As elected bodies local councils are expected to express and realize the will of the 
citizens in the respective administrative-territorial units. In theory, local councils can exert some influence over their respective administrative bodies. For example, in Kazakhstan, they have the authority to pass a vote of no confidence in the head of local state administration by a majority of two-thirds of all members and to request his or her dismissal from office from the president or superior governor (article 87 of the Kazakh Constitution) [64]. However, this is not the case in practice as the heads of local administration enjoy absolute power in the management of local affairs. [e.g. 86]. As all governors are appointed, local councils cannot exert significant influence on governors. Even though governors periodically report to the local council on the current situation of the territory, this process is of mainly a symbolical nature $[3 ; 11$; 47; 64]. The situation is especially problematic in Tajikistan and Uzbekistan where the governors of the regional, city or district state administration simultaneously exercise executive authority and serve as local council chairmen [11; 47]. This means it is very difficult to distinguish between the functions of local state administration and local self-government bodies, since the same individual, i.e. governor heads both branches of power.

In addition to regional and district state administrations, there are also sub-district level governance structures in towns and rural areas. These sub-district structures were part of state farms, collective farms and enterprises during the Soviet era, but shortly after independency all four Central Asian countries, coming on the heels of global decentralization and good governance discourse, have revamped these structures, assigning them new legal status as 'local self-government bodies of citizens' [40]. Sub-district level self-government institutions are called aiyl okmotu in Kyrgyzstan, aul in Kazakhstan, jamoat in Tajikistan and mahalla committees in Uzbekistan. Although they are called differently, their responsibilities and conditions are quite similar in the sense that they assist district/town administrations in implementing local development projects, collecting taxes, administering social welfare programs, maintaining and repairing roads, disposing of waste, ensuring security and order, removing garbage, maintaining playgrounds and sports fields, and many other tasks that are of local importance [e.g. 3; 11; 47; 82; 112; 7]. Similarities can also be found when we look at the financial conditions and position of sub-district self-governments vis-a-vis higher level administrations: (a) the chairmen of subdistrict self-governments report to the head of district or town administrations; (b) sub-district self-governments do not have solid financial base and are entirely dependent on budget allocations from district/town administrations, voluntary labor and individual donations. This means local self-governance institutions do not have real capacity to act as sites of local democracy and participation, merely serving as a sub-district extension of local state administrations.

The lowest tier in the system of local government is a traditional communitybased (pre-Soviet) governance structures. There are various types and forms of community-based structures, such as community-based alternative dispute resolution mechanism (e.g. Aksakal court in Kyrgyzstan, Aksakal reconciliation in Uzbekistan and Tajikistan, Council of Aksakals in Kazakhstan), informal community gathering 
(e.g. kurultai in Kyrgyzstan, informal mahalla gathering in Uzbekistan, guzar and tabagy in Tajikistan), community-based voluntary work (e.g. assar in Kazakhstan, hashar in Uzbekistan) and religious organizations (mosque, especially in Uzbekistan and Tajikistan). The analysis of scholarly literature shows that for many Central Asians traditional community-based structures are more legitimate and easily accessible than the formal state structures [e.g. 94;41;97;63;30;69;48; 5; , 89; $103 ; 105 ; 106 ; 105 ; 50 ; 13]$.

\section{Local Government Situation in Central Asia}

Following the collapse of the Soviet Union in 1991, Central Asian countries embarked on the highly complex task of reforming their public administration systems. Under the influence of global decentralization and good governance agenda, Central Asian countries proclaimed their commitment to the ideals of democracy, human rights, market economy, and rule of law. The implementation of these commitments however proved to be a daunting task, since each of these countries had to deal with their Soviet legacy and internal power structures, i.e. weak state institutions, poorly developed national identities, and entrenched sub-national political networks [73; 84]. In all four Central Asian republics, the relationship between local state administration and central government is often based on subordinate relations rather than on mutual cooperation. The system of local public administration in Central Asian countries continues to remain highly dependent on the center, justified by the ruling elites as a necessity for maintaining political stability and territorial integrity during the transition period $[23 ; 3 ; 86 ; 60 ; 45 ; 38 ; 88]$.

One possible inference is that the absence of real administrative reforms in Central Asia could be explained with reference to ruling elites' perception of local self-government. Hence, local self-government is interpreted merely in terms of citizens' active participation in local government, but other key condition for local self-government, i.e. autonomy of local self-government structures from the state, is largely neglected or seen as a destabilizing factor that undermines public order and security [e.g. 70; 45; 57]. Similar hierarchical patterns can also be found when it comes to the relations between local executive bodies and local councils. As studies indicate, the most powerful actor in the local government, be it at the district, city or regional level, is a governor, who is appointed by the central government and primarily accountable to the country's president. Local councils merely serve as a symbol of local level legislative bodies, but in practice local governor is the main power breaker $[3 ; 11 ; 47 ; 64]$.

Although local governments in all four Central Asian countries function in a similar environment, some differences exist among Central Asian countries when we measure the scope of reforms they have undertaken, at least from the point of view of formal reforms (i.e. de-jure decentralization). In this regard, Kazakhstan is the most active reformer in the region, since it carried out substantial reforms at the local level by holding pilot election of governors, establishing Western style civil service system, and privatizing some of the public services. Kyrgyzstan has also taken some steps 
towards greater local autonomy by holding local elections for village and town governors. In comparison to Kazakhstan and Kyrgyzstan, other Central Asian countries have undertaken less reforms due to political turmoil (e.g. Tajikistan), or reform paths they have chosen have been largely conservative in nature (Uzbekistan and Turkmenistan). For instance, Uzbekistan showed less willingness to undertake neoliberal reforms, retaining the state as the key actor and manager in the economy. Due to the outbreak of civil war shortly after independence, no significant reforms were undertaken in Tajikistan in the 1990s and some forms of first-generation reforms started to come only after 2000. Nevertheless, Tajikistan seems to be more open to reform initiatives than Uzbekistan and Turkmenistan. Perlman and Gleason (2007) suggest that administrative reform in Central Asia is to a great extent an outcome of external pressure from international organizations, than of internal political shifts. Hence, one explanation for the variance in reform paths in the region is that countries that were dependent on foreign direct investment and development aid were more prone to initiate reforms.

The above suggests that local government in Central Asia functions in a rather complex socio-political environment dominated by powerful internal hierarchies. Public administration systems of Central Asian countries can hardly been regarded 'decentralized' in the sense that the local governments are heavily dependent on central government [see e.g. 57; 92; 43]. Even in Kazakhstan, where government has been ambitiously introducing Western style public administration structures, the administrative reforms are often illogical, barely implemented and deviations from formal requirements have become commonplace $[18 ; 57 ; 31]$. All in all, Central Asian countries share similar characteristics in terms of their institutional underdevelopment, centralization of power, scarcity of economic resources (with the exception of Kazakhstan), and the dominance of informal processes and structures. Due to their Soviet legacy and administrative traditions, the processes and attempts of decentralization are slow and face strong resistance from various power structures. Accordingly, local governments continue to remain dependent on the center in all matters and from the point of political, administrative and financial decentralization. These deficiencies are due to combination of many factors, such as path dependencies, dominance of informal institutions, authoritarian political culture, wealth and socio-economic indicators, weak local legislative bodies and geopolitical situation of the region. The question is how these similarities and differences influence the challenges and opportunities local governments in Central Asia face. Accordingly, in the next section the main challenges and problems of local government in Central Asia will be presented.

\section{The Capacity of Local Government in Central Asia}

This section aims addresses the following two questions: (a) How do local governments in Central Asia perform, with regard to service delivery and good governance? (b) What are the main challenges that local governments face? First, I will provide a brief assessment of the capacity of local government in Central Asia, 
focusing on the quality of service delivery and satisfaction and opinion of citizens about local government.

One of the most important criteria used by the citizens to assess the performance of local governments is the quality and accessibility of local public services [86]. However, there are only few studies that can provide some data on citizens' satisfaction with local public services in Central Asia. In Kazakhstan, as Wilson et al. (2002) found, quality of services provided by local government in general do not meet the standards desired by service users, as 51 per cent of respondents stated that they are not satisfied with the quality of services provided by local government. Another pertinent literature is Neema Noori's [80] study of decentralization processes in Uzbekistan. As Noori argues, decentralization had a negative impact on public service delivery in Uzbekistan, as it was not accompanied by corresponding resources and consequently worsened the quality and accessibility of public services. Interestingly enough, most citizens in Kyrgyzstan are aware of the problematic financial situation of local governments and hence they rarely put pressure on them to address their needs and problems [8].

One common tendency in the region is that central government delegates enormous service delivery responsibilities to local governments without providing adequate funding $[3 ; 80 ; 8 ; 48 ; 76 ; 84 ; 66]$. Thus, local governments assume huge service delivery responsibilities without having sufficient resources to implement them. In Kazakhstan, for example, the central government legally absolved itself of the social welfare obligations by transferring them to regional governments, but without providing sufficient revenue basis. As a result, regional governments were not able to meet their service delivery responsibilities and had to cut back on social spending which in turn drastically deteriorated the quality of public service provision [84]. Analogous pattern can also be found in Tajikistan where local government is financially weak and the system of public services is highly unstable. For instance, many of the welfare entitlements (that the local governments (jamoats) are responsible for) are not paid at all. The health care services are available on a userpays basis, with many people unable to get access to even the most basic services. The quality of public education is worsening. NGO's provide some form of social assistance to the poor families, though the scope of their assistance is limited [68; 53]. One evolving trend is the emergence of civil society organizations that provided alternative forms of welfare support to the population. One of the main focus areas of civil society organizations is the health sector [35].

The situation with health care provision is also problematic. In all four Central Asian countries health care systems are highly reliant on informal forms of financing. Most patients have to make informal payments to medical professionals in order to receive proper medical treatment, even though public authorities claim that citizens are entitled to free medical care. A similar situation can also be observed in the field of education. Due to their vulnerable financial situation, local governments do not have sufficient resources to maintain local schools and provide adequate number of books or build modern sports facilities. The parents usually cover these expenditures. 
One trend common to all Central Asian countries is a growing importance of traditional community-based organizations in people's everyday life. Due to the incapacity of the state to provide adequate social services at the local level, traditional community-based structures have evolved to respond to declining state social welfare capacity in post-Soviet period, acting as a pseudo local government entity given the failure of existing regime to provide much need development in rural Uzbekistan. Another collective action in Central Asia that emerged in response to the failure of formal structures is a mass migration of labor force from Uzbekistan, Tajikistan and Kyrgyzstan to Russia. This tendency is particularly visible in Tajikistan where remittances sent from Russia constitute almost half of the country's GDP.

In the next sections, I will discuss the main trends and challenges hindering local government reform processes in the region. More specifically, I elaborate on the four core challenges: (a) problematic financial situation of local governments, (b) authoritarian regimes, (c) informal decentralization, and (d) clans and regional patronage networks

\section{The Problematic Financial Situation of Local Governments in Central Asia}

Local public finances are one of the most controversial issues on the decentralization agenda in Central Asia [86]. Studies show that local governments in the region have limited financial autonomy and are strongly dependent on the central government $[23 ; 86 ; 82 ; 2 ; 38 ; 40 ; 71 ; 14 ; 28 ; 26]$. Local budgets mainly consist of transfers from the central government and local tax revenues. Local budget planning is centralized and closely tied to the national budget, which implies that the revenue basis of the local budgets are determined by the central government bodies and local governments cannot independently establish tax rates or collect their own revenues through local taxes, with the exception of some insignificant local fees, taxes and duties, e.g. land tax. National budget funds are redistributed among different regions by deducting budget surpluses from regions that perform well and allocating in the form of subventions, subsidies, or equalization transfers to vulnerable regions that cannot cover their needs. The revenues collected from local taxes constitute a small portion of local government's revenues, insufficient for covering even the basic expenses. Hence, the ability of local governments to raise their own revenues is considerably limited and they remain dependent on transfers from the central government for fulfilling their service delivery functions.

Moreover, local governments' financial autonomy is often undermined by stipulations in various national laws that allow central government bodies to interfere directly into the most basic local government functions [86]. Therefore, they neither enjoy fiscal autonomy nor are transfers from the center sufficient to meet their service delivery needs $[29 ; 25 ; 54]$. Studies suggest that there is a need to introduce a new mechanism for inter-budgetary relations that provides local governments with the incentive to increase local revenues $[3 ; 11 ; 86]$.

In their comparative study of decentralization and delivery of public services in Asia, Ghuman and Sing [39] found that decentralization improved the quality and 
accessibility of public services where it was accompanied by sound financial resource base (ibid.). Similarly, one challenge common to local governments in all Central Asian countries is the gap between their economic and social functions and the meagre financial means available for their implementation. Local governments do not have sufficient resources to adequately maintain social infrastructures, majority of which was built during the Soviet period. For instance, in Uzbekistan, local governments are tasked with the responsibility to support local development, but in practice they neither have real ownership rights over local property, nor can manage local funds or material, technical and natural resources. Moreover, local governments do not have significant influence on privatization processes (with the exception of some small-scale local privatization programs), which deprives them of the possibility to generate significant revenues [11]. Special case in the region is Tajikistan where local governments possess their own source of revenue and have the right to develop and implement their own budgets own sources of revenue [3]. In spite of their relative autonomy, local governments in Tajikistan are financially very dependent on the center as the scope of their revenues is not sufficient to meet the local service delivery needs. Thus, Central Asian countries have made little or no progress in developing truly autonomous local governments.

\section{Local Government Reform in Authoritarian Regimes}

Although Central Asian ruling elites make all sorts of bold claims about their strong intention to give more autonomy to local governments, their system of administration still remains highly centralized [see e.g. 60; 86]. In Central Asia, as Saner et al. [92] argue, problems in implementing local government reforms are closely connected with the general problems with authoritarianism. Local governments are highly dependent on the central government in all levels administratively, financially and politically. Over-dependence on central government limits the ability of local governments to support local development. Under these circumstances political and civil servants at all levels do not feel any accountability to citizens, but rather they try to meet the expectations of those who have power and authority to hire them $[14 ; 15]$. The malfunctioning local governments are mainly the outcome of centralized governments that do not delegate any real autonomy to local administrations [11]. Public participation in the local politics is almost non-existent and local elections are merely used to assert and legitimize central government's influence in the periphery. Openness and transparency are not viewed as a norm in day-to-day operation of local administrations. Local government officials care less about informing people about their work or considering their opinions on the level and quality of public services, but they are chiefly concerned with fulfilling the orders and expectations of the central government.

The power and functions between central state agencies and local governments are ambiguously distributed, which largely derives from the deficiencies in national laws that do not clearly specify the functions and powers across various tiers of government [86; 25]. Most administrative decisions concerning district and regional 
public service delivery issues are taken by the central government bodies, in which a hierarchy of power starts at the ministry, followed by ministry's main regional department, followed by the district or city unit. Ministries control the daily activities of their territorial agencies and directly appoint their heads, in coordination (Uzbekistan) or without coordination (Kazakhstan) with the governor [11; 64], which implies that the territorial units of the ministries are accountable to their central bodies and thereby rarely coordinate with local governments.

It is assumed that local councils are more effective and interested in monitoring the activities of local government officials than distant civil servants and auditors [e.g. 9]. But this is not the case in Central Asia where local councils, despite having official status as local legislative bodies, in practice are subordinated to local state administrations. In addition, decentralization reforms do not promote local autonomy and democracy but paradoxically increase the influence of central government in local arenas. Hence, institutions of self-governance fulfil completely different functions and aims than the officially declared ones ('institutional pseudomorphism'). One good example is a mahalla reforms in Uzbekistan that transformed mahalla into an 'eyes and ears' of the state, thereby expanding the reach of the state in local areas [see e.g. 44; 80]. Thus, there is very little or no understanding of the real essence of local government reform in the region. As Abdukhalilov [1] notes, in Uzbekistan administrative reforms are often understood as a cutback in staff or an attempt to save money. More importantly, administrative reforms do not contain any single paragraph about the necessity to change the hierarchical norms and mentality of managers (ibid.). Given the nature of political regimes in Central Asia it is quite understandable that local government reforms merely remain on the paper and authoritarian regimes continue to exert strict control over local government.

\section{Informal Decentralization}

The scholars of development studies argue that decentralization can reduce the cost of public service delivery, enhance accountability, promote local social and economic development, and decrease the level of corruption $[99 ; 81 ; 83 ; 77 ; 6 ; 110$; 36]. However, the political and socio-economic context of Central Asian countries does not fit into this narrative, as decentralization occurs in this region not because of the intentions of the center to grant autonomy to local governments, but due to the covert resistance of regional and local elites to centrally designed policies and laws [e.g. 23; 84]. Moreover, there is no sufficient infrastructure in place (e.g. effective audit and budgetary control, independent judiciary, accountability mechanisms) that can ensure the effective allocation of resources at the local and regional level [61]. Hence, in Central Asia we find qualitatively different form of decentralization that comes more often from below (i.e. the regional-local government) than from above, occurring mainly through informal rules and networks. Hence, decentralization takes on a form that is much more de facto (unofficial) than de jure (official) [e.g. 61; 62; 57]. Libman [57] defines this process 'informal decentralization' as it is based on informal, unwritten rules, less transparent and barely helps the formation of favorable 
economic and social conditions in regions. Most sociological and anthropological studies have revealed how the regional administrations in Central Asia have strategically used the informal powers they have 'captured' for rent-seeking purposes rather than for promoting local social and economic development $[93 ; 61 ; 45 ; 111$; $20 ; 2006 ; 100 ; 57 ; 58 ; 67 ; 101]$. Likewise, central government in Central Asian countries is more prone to limit the independent actions and autonomy of regional leaders than to decentralize authority.

Kazakhstan's 'informal decentralization' experience in the 1990s deserves special attention. As Libman [57] describes, between 1991 and 1999, Kazakhstan has experienced severe economic hardships that led the regional governors to introduce their own policies partly conflicting with the central ones. Moreover, the flow of foreign direct investment into the oil-rich Western regions of the country strengthened the position of local elites vis-a-vis the center, enabling them to influence the appointment of regional governors. These developments deepened the alreadyexisting regional disparities, since the economically successful regions were able to retain a higher portion of tax revenue generated from their territory, while regions with little revenue basis continued to receive meagre funds from the center, insufficient to meet their service delivery responsibilities. However, post-1999 economic boom changed the course and dynamics of power relations between the center and periphery. First, the center utilized the personnel selection schemes as the main tool of recentralization, appointing former members of the central government as governors. Second, the central government created new national oil company KazMunaiGaz with the aim of re-establishing control over oil and gas resources of the regions. Third, center altered the borders of some regions and moved the capital from Almaty to Astana, which resulted in the reduction of political autonomy of governors. In doing so, the central government increased the dependence of regions on budgetary transfers and succeeded in reducing the autonomy of regions in order to preserve political stability in the long term.

Some patterns of 'informal decentralization' have also been observed in Uzbekistan. The central government in Uzbekistan continually rotates and changes heads of regional and district governors in order to effectively centralize power and to reduce the rent-seeking practices. In spite of these strategies, regional elites and networks find various ways to bend the centrally designed policies and laws. The most pertinent literature in this respect is the case study of rent-seeking strategies among local public prosecutors in Samarkand region by Markowitz [67] in which the author illustrates how an attempt to extend state power to the regional arenas unintentionally enhanced the control of local elites over extractive processes. Ilkhamov [45] describes the conflicting economic and political interests between central government, local producers and regional elites with respect to agricultural policy. In Uzbekistan, as Ilkhamov demonstrates, the policies of central government are permanently undermined by the destabilizing claims of a recalcitrant periphery, represented by regional elites within the state apparatus. Another relevant literature is Tommaso Trevisani's [100] article on the struggles between central government and 
local elites over land use. As Trevisani describes, after independence Uzbek government was no longer able to ensure the regular payment of wages and to provide adequate public services. But at the same time central government maintained firm grip over the returns of agriculture and extracted all profits from cotton sales, thereby depriving local elites of their share of rents from the business with cotton. The reaction of local elites was to invent alternative sources of income, which they did by forcing local producers (farmers) to increase the sector of agriculture not devoted to cotton production, as this is the sector that local elites can control autonomously and that enables them to generate the rents that are no longer available through the state budget. The negative consequence of these informal measures was that local producers had to shoulder a double responsibility imposed on them by the central government and local elites.

In politically unstable countries of the region, Tajikistan and Kyrgyzstan, where the central government is relatively weak vis-a-vis regional interests, decentralization may not only lead to more rent-seeking activities but also risk greater instability [61]. In Tajikistan, the central government faces strong resistance from regional networks and groupings. Regional leaders, having legitimacy in the local arenas, compete for access to natural, financial and administrative resources and set the rules of the game in their 'enclaves' [111]. Luong [59] argues that these regional interests and political identities influence the core policy processes not only in the regions, but also they manifest themselves in the decision-making at the central level.

As seen above, regional leaders have more control over the local resources in practice than they are granted on paper. However, such informal form of decentralization can hardly be seen as a positive development, since they are neither transparent nor promotes local economic and social development. The decentralization described above was not the outcome of carefully planned policies but rather it occurred largely due to inability of the center to implement adequate local development policies. Similar conclusions have also been made in recent literature on colonial administration in Africa and Asia where authors showed that devolving power to tribal chiefs and other local elites had very little to do with promoting democracy and local economic development [16; 17; 52; 75; 10; 65; 42].

\section{Clans and Regional Patronage Networks}

In all four Central Asian countries clans and regional patronage networks have a strong presence in the governing structures and dominate key political processes [23; $59 ; 45 ; 46 ; 111 ; 100 ; 57 ; 67]$. The relations and behavior of bureaucrats within public administration structures are not based on formal rules, but are mainly driven by informal rules and networks. When discussing the relations between the centerperiphery relations in Central Asia, some authors mention the existence of 'informal constitution', i.e. the system of informal rules governing relations within the elite [59; 57; 95]. Therefore, one of main challenges, influencing local government situation in Central Asia, are clans and patronage groups. Studies demonstrate that governments of Central Asian countries, even if they have accepted Western governance models 
and theories, in practice, they are largely influenced by existing informal and formal structures $[57 ; 4]$. As formal state structures weakened during the post-Soviet transition, clans and patronage networks emerged as powerful political actors, vying for control over key sectors of the state and economy $[93 ; 19 ; 20 ; 21 ; 2 ; 12 ; 78 ; 1$; $46 ; 100 ; 24]$.

Much of the scholarly literature argues that clans have a negative influence on public administration and governance processes Central Asia, leading to rampant corruption, favoritism, nepotism and a weak rule of law. For instance, in Tajikistan statehood and governance hardly function at grassroots level. Local governance is increasingly exercised by alliances of local social forces (big landowners, religious structures, foreign and domestic NGOs, international organizations) that provide alternative means of survival for citizens [111]. Babajanian also observes identical pattern in Kyrgyzstan where the political and economic relations between the central government and local administrations are largely based around patron-client networks [8]. Kazakhstan also shares these problems. Despite the adoption of Civil Service Law, decision-making processes and the recruitment of civil servants are largely based on personal loyalty, friendship, or blood connections [31].

\section{Conclusion}

1. There is a widespread belief that local governments are better positioned to deliver public services due to their immediate proximity to people and better awareness of the local problems than central state agencies. However, the growing body of literature argues that decentralization can exacerbate inter-regional disparities, can undermine macroeconomic and political stability and create favorable conditions for corrupt transactions and diminish economies of scope. Prud'homme argues that decentralization is a 'potent drug' that is better not applied when the symptoms of the disease are misinterpreted.

2. Hence, agreeing with the aforesaid literature, this article clearly demonstrates a need to consider the local context when applying global (Western-centric) governance and decentralization models in Central Asia. As shown in earlier sections, socio-political context of Central Asia largely varies from the Western one and that administrative reform initiatives produce rather different outcomes. Decentralization in Central Asia largely takes on the form of a geographically based struggle between state elites for control over access to resources. These regional power structures are less concerned with local development issues but rather they are more inclined to seek rent. Libman also claims that there is no evidence that local government reforms could be beneficial and increase the quality of public services. Likewise, further decentralization only serves to intensify the struggle among governing elites for control over sphere of influence. Consequently, any attempt to improve the quality of public administration in Central Asia should be aware of the covert power of these regional forces and that local government reform initiatives should reckon with the socio-political realities of the region. 
3. As the results demonstrate, the core challenge hindering local government reform comes from the persistence of authoritarian style administrative practices. Although there have been some local government reform initiatives in the region, but they remained 'in paper' and had little or no effect on governance processes in the region and, while in practice local government continue to be subordinated to central government in all public policy issues, be it education sector, taxation, health care, welfare or agriculture. Therefore, local governments do not have real capacity to adequately address the needs and concerns of citizens, as they are merely concerned with implementing centrally designed policies. Tax revenue is not sufficient for fiscal autonomy of local governments and local governments heavily dependent on interbudgetary transfers. Since local governments do not have a solid financial base and the center takes important public policy decisions, little or no possibility exists at the local level for citizens to voice their concerns about public services. One visible consequence is an emergence of alternative (to the state) decentralization strategies and citizens' informal coping strategies. We can observe the tendency of a return to older structures of clans, lineages, extended families, and personal networks as a coping strategy. These alternative strategies are short-term solutions, have little to do with local development issues and negatively influence governance trajectories in the region. They undermine the rule of law, foster clientelistic culture and promote social hierarchies and inequalities. Hence, local government reform is not simply a matter of introducing Western-style governance structures or granting more autonomy to local actors. It is, more importantly, about understanding the local socio-political context and promoting socio-economic change.

\section{References}

1. Abdukhalilov, A., 2007. Stages and Special Features of the Administrative Reforms in the Republic of Uzbekistan. Central Asia and the Caucasus, (6 (48)).

2. Abdullaev, K., 2004. Current local government policy situation in Tajikistan. Tajikistan at a crossroad: The Politics of Decentralization. Bishkek, 8-16.

3. Alymkulov, E. and Kulatov, M., 2001. Local government in the Kyrgyz Republic. In: V. Popa and I. Munteanu, eds. Developing New Rules in the Old Environment. Local governments in Eastern Europe, in the Caucasus and in Central Asia. Budapest: Local Government and Public Service Reform Initiative, Open Society Institute Europe, 522600.

4. Aminova, M., 2011. Essays on the Analysis of Trends Affecting Governance in Transition Countries. PhD Thesis. Vrije Universiteit Brussel, Brussels.

5. Aminova, M. and Jegers, M., 2011. Informal Structures and Governance Processes in Transition Economies: The Case of Uzbekistan. International Journal of Public Administration, 34 (9), 579-590.

6. Arikan, G.G., 2004. Fiscal decentralization: A remedy for corruption? International Tax and Public Finance, 11 (2), 175-195.

7. Babajanian, B.V., 2006. The social exclusion framework and poverty reduction strategy in Tajikistan. Central Asian Survey, 25 (4), 403-418. 
8. Babajanian, B.V., 2007. Local Governance and Citizens' Welfare in Kyrgyzstan. Unpublished working paper. Social Research Center of the American University of Central Asia (AUCA), Bishkek.

9. Bardhan, P.K. and Mookherjee, D., 2001. Corruption and decentralization of infrastructure delivery in developing countries (working paper).

10. Barkey, K., 1996. Bandits and Bureaucrats: The Ottoman Route to State Centralization. Ithaca, NY: Cornell University Press.

11. Bektemirov, K. and Rahimov, E., 2001. Local Government in Uzbekistan. In: V. Popa and I. Munteanu, eds. Developing New Rules in the Old Environment. Local governments in Eastern Europe, in the Caucasus and in Central Asia. Budapest: Local Government and Public Service Reform Initiative, Open Society Institute Europe, 469-520.

12. Berdikeeva, S., 2006. National identity in Kyrgyzstan: the case of clan politics. In: The Association for the study of Nationalities' 11th Annual World Convention. ' Nationalism in an Age of Globalization.’ New York: Columbia University. March. 23-25.

13. Beyer, J., 2015. Customizations of Law: Courts of Elders (Aksakal Courts) in Rural and Urban Kyrgyzstan. PoLAR: Political and Legal Anthropology Review, 38 (1), 53-71.

14. Bhuiyan, S.H., 2010. Decentralization and Local Governance in Kazakhstan. International Journal of Public Administration, 33 (12-13), 658-672.

15. Bhuiyan, S.H. and Francis Amagoh, 2011. Public sector reform in Kazakhstan: issues and perspectives. International Journal of Public Sector Management, 24 (3), 227-249.

16. Boone, C., 1994. States and Ruling Classes in Postcolonial Africa: The Enduring Contradictions of Power. In: J.S. Migdal, A. Kohli, and V. Shue, eds. State Power and Social Forces: Domination and Transformation in the Third World. New York: Cambridge University Press, 108-140.

17. Boone, C., 2003. Decentralization As Political Strategy In West Africa. Comparative Political Studies, 36 (4), 355-380.

18. Centr Aktual'nykh Isslegovaniy, A., 2007. Administrativnaya Reforma v Kazakhstane: Kuda Dvigatsya Dal'she?. Mimeo.

19. Collins, K., 2003. The Political Role of Clans in Central Asia. Comparative Politics, 35 (2), 171-190.

20. Collins, K., 2006. Clan Politics and Regime Transition in Central Asia. Cambridge: Cambridge University Press.

21. Collins, K., 2009. Economic and Security Regionalism among Patrimonial Authoritarian Regimes: The Case of Central Asia. Europe-Asia Studies, 61 (2), 249-281.

22. Coudouel, A. and Marnie, S., 1999. From Universal to Targeted Social Assistance: An Assessment of the Uzbek Experience. MOCT-MOST: Economic Policy in Transitional Economics, 9 (4), 443-458.

23. Cummings, S.N., 2000. Kazakhstan: Centre-Periphery Relations. London: Royal Institute of Internal Affairs.

24. Cummings, S.N., 2013. Understanding Central Asia: Politics and Contested Transformations. Routledge.

25. Dabla-Norris, E., 2006. The Challenge of Fiscal Decentralisation in Transition Countries. Comparative Economic Studies, 48 (1), 100-131. 
26. Djalilov, K. and Piesse, J., 2011. Financial Development and Growth in Transition Countries: A Study of Central Asia. Emerging Markets Finance and Trade, 47 (6), 4-23.

27. Drechsler, W., 2014. What is Islamic Public Administration and why should we study it in the 'Second World'? Administrative Culture, 15 (2), 123-142.

28. Drechsler, W., 2015. Debate: Islamic PA-does it exist, what is it, and why and how should we study it? Public Money \& Management, 35 (1), 63-64.

29. Dunn, J. and Wetzel, D., 1999. Fiscal Decentralization in Former Socialist Economies: Progress and Prospects. Proceedings. Annual Conference on Taxation and Minutes of the Annual Meeting of the National Tax Association, 92, 242-250.

30. Earle, L., 2005. Community development, 'tradition' and the civil society strengthening agenda in Central Asia. Central Asian Survey, 24 (3), 245-260.

31. Emrich-Bakenova, S., 2009. Trajectory of Civil Service Development in Kazakhstan: Nexus of Politics and Administration. Governance, 22 (4), 717-745.

32. D' Encausse, H.C., 1988. Islam and the Russian Empire: Reform and Revolution in Central Asia. University of California Press.

33. Epstein, P., 2004. Assessment of Intergovernmental Relations and Local Governance in the Republic of Uzbekistan [online]. Available from: http://www.urban.org/publications/411152.html [Accessed 13 Feb 2015].

34. Ergashev, B., Iusupov, I., Pogrebniak, A., Korenev, I., Allaev, B., Gaibullaev, O., Usmanov, S., Gasanova, N., and Saifulin, R., 2006. Public Administration Reform in Uzbekistan. Problems of Economic Transition, 48 (12), 32-82.

35. Ewoh, A., Nazarova, F., and Hill, R., 2012. Civil Society Organizations and Policy Process in Tajikistan. Journal of Emerging Knowledge on Emerging Markets, 4 (1).

36. Freille, S., Haque, M.E., and Kneller, R., 2007. Federalism, decentralisation and corruption. Working Paper, Nottingham, UK: University of Nottingham.

37. Freizer, S., 2004. Tajikistan local self-governance: a potential bridge between government and civil society. Tajikistan at a crossroad: The Politics of Decentralization. Bishkek, 1725.

38. Freizer, S., 2005. Neo-liberal and communal civil society in Tajikistan: merging or dividing in the post war period? Central Asian Survey, 24 (3), 225-243.

39. Ghuman, B.S. and Singh, R., 2013. Decentralization and delivery of public services in Asia. Policy and Society, 32 (1), 7-21.

40. Giffen, J., Earle, L., and Buxton, C., 2005. The development of civil society in Central Asia. Intrac Oxford.

41. Haghayeghi, M., 1996. Islam and Politics in Central Asia. New York: St Martin's Press.

42. Heller, P., 2001. Moving the State: The Politics of Democratic Decentralization in Kerala, South Africa, and Porto Alegre. Politics \& Society, 29 (1), 131-163.

43. Hoffmann, K., 2010. The EU in Central Asia: successful good governance promotion? Third World Quarterly, 31 (1), 87-103.

44. Human Rights Watch, 2003. From House to House: Abuses by Mahalla Committees. New York: Human Rights Watch. 
45. Ilkhamov, A., 2004. The Limits of Centralization: Regional Challenges in Uzbekistan. In: The Transformation of Central Asia. States and Societies from Soviet Rule to Independence. Ithaca, NY: Cornell University Press, 159-181.

46. Ilkhamov, A., 2007. Neopatrimonialism, Interest Groups and Patronage Networks: The Impasses of the Governance System in Uzbekistan. Central Asian Survey, 26 (1), 65-84.

47. Ilolov, M. and Khudoiyev, M., 2001. Local government in Tajikistan. In: V. Popa and I. Munteanu, eds. Developing New Rules in the Old Environment. Local governments in Eastern Europe, in the Caucasus and in Central Asia. Budapest: Local Government and Public Service Reform Initiative, Open Society Institute Europe, 603-648.

48. Kandiyoti, D., 2007. Post-Soviet Institutional Design and the Paradoxes of the Uzbek Path. Central Asian Survey, 26 (1), 31-48.

49. Khalid, A., 2000. Society and politics in Bukhara, 1868-1920. Central Asian Survey, 19 (3-4), 364-393.

50. Khalid, A., 2014. Islam after communism: religion and politics in Central Asia. Berkeley, CA: University of California Press.

51. Klebleyev, A., 2014. Islamic Legacy beyond Islam: The Case of Uzbekistan. Administrative Culture, 15 (2), 143-156.

52. Kohli, A., 1994. Centralization and Powerlessness: India's Democracy in a Comparative Perspective. In: J.S. Migdal, A. Kohli, and V. Shue, eds. State Power and Social Forces: Domination and Transformation in the Third World. New York: Cambridge University Press, 89-107.

53. Ledgerwood, J. and Wilson, K., 2013. Community-based financial services: a spectrum of providers. Enterprise Development and Microfinance, 24 (2), 91-103.

54. Leschenko, N. and Troschke, M., 2006. Fiscal decentralization in centralized states: the case of Central Asia. Arbeiten aus dem Osteuropa-Institut München, No. 261.

55. Levi, S.C., 2007. The Ferghana Valley at the crossroads of world history: the rise of Khoqand, 1709-1822. Journal of Global History, 2 (02), 213-232.

56. Levi, S.C., 2012. Early Modern Central Asia in World History. History Compass, 10 (11), 866-878.

57. Libman, A., 2008. Economic role of public administration in Central Asia: Decentralization and hybrid political regime [online]. Available from: http://mpra.ub.unimuenchen.de/10940/ [Accessed 10 Dec 2014].

58. Libman, A., 2010. Cycles of Decentralization in the Post-Soviet Space. Russian Politics and Law, 48 (1), 8-20.

59. Luong, P.J., 2000. Sources of Institutional Continuity: the Soviet Legacy in Central Asia. In: Annual Meeting of the American Political Science Association, Washington, D.C., August 31-September 2, 2000.

60. Luong, P.J., 2002. Institutional Change and Political Continuity in Post-Soviet Central Asia: Power, Perceptions, and Pacts. Cambridge: Cambridge University Press.

61. Luong, P.J., 2003. Political obstacles to economic reform in Uzbekistan, Kyrgyzstan, and Tajikistan: Strategies to move ahead. In: World Bank paper prepared for the Lucerne Conference of the CIS-7 Initiative. 20-22. 
62. Luong, P.J., ed., 2004. The Transformation of Central Asia. States and Societies from Soviet Rule to Independence. Ithaca, NY: Cornell University Press.

63. Lutz, G. and Linder, W., 2004. Traditional structures in local governance for local development. Berne, Switzerland: University of Berne, Institute of Political Sciene.

64. Makhmutova, M., 2001. Local government in Kazakhstan. In: V. Popa and I. Munteanu, eds. Developing New Rules in the Old Environment. Local governments in Eastern Europe, in the Caucasus and in Central Asia. Budapest: Local Government and Public Service Reform Initiative, Open Society Institute Europe, 403-468.

65. Mamdani, M., 1996. Citizen and Subject: Contemporary Africa and the Legacy of Late Colonialism. Princeton, N.J: Princeton University Press.

66. Mandler, A., 2010. The influence of local governance on agricultural advisory services in Tajikistan.

67. Markowitz, L.P., 2008. Local Elites, Prokurators and Extraction in Rural Uzbekistan. Central Asian Survey, 27 (1), 1-14.

68. Martin, J., 2002. Can magic bullets hurt you? NGOs and governance in a globalised social welfare world : a case study of Tajikistan.

69. Masaru, S., 2006. The Politics of Civil Society, Mahalla and NGOs: Uzbekistan. In: L. Osamu and U. Tomohiko, eds. Reconstruction and Interaction of Slavic Eurasia and Its Neighbouring Worlds. Sapporo: Slavic Research Center, Hokkaido University, 335-370.

70. Matsuzato, K., 2001. An island of democracy? Local reforms in Kyrgyzstan 1990-2000. Central Asia and the Caucasus, 4 (10), 142-154.

71. McMann, K., 2007. The Shrinking of the Welfare State: Central Asians' Assessments of Soviet and Post-Soviet Governance. In: J. Sahadeo and R. Zanca, eds. Everyday Life in Central Asia: Past and Present. Bloomington, IN: Indiana University Press, 233-247.

72. De Mello, L.R., 2000. Fiscal Decentralization and Intergovernmental Fiscal Relations: A Cross-Country Analysis. World Development, 28 (2), 365-380.

73. Melvin, N.J., 2004. Authoritarian Pathways in Central Asia: A Comparison of Kazakhstan, the Kyrgyz Republic, and Uzbekistan. Democracy and Pluralism in Central Eurasia, London: Frank Cass, Cummings Center Series, 127-128.

74. Micklewright, J. and Marnie, S., 2005. Targeting Social Assistance in a Transition Economy: The Mahallas in Uzbekistan. Social Policy and Administration, 39 (4), 431447.

75. Migdal, J.S., Kohli, A., and Shue, V., eds., 1994. State Power and Social Forces: Domination and Transformation in the Third World. Cambridge; New York: Cambridge University Press.

76. Mirzoev, T.N., Green, A.T., and Newell, J.N., 2007. Progress towards health reform in Tajikistan. Journal of Health Organization and Management, 21 (6), 495-505.

77. Mohan, G. and Stokke, K., 2000. Participatory development and empowerment: the dangers of localism. Third world quarterly, 21 (2), 247-268.

78. Naumkin, V., 2006. Uzbekistan's state-building fatigue. The Washington Quarterly, 29 (3), 127-140.

79. Nemec, J. and Vries, M.S. de, 2012. Global Trends in Public Sector Reform. Brussels: De Boeck publishers. 
80. Noori, N., 2006. Expanding State Authority, Cutting Back Local Services: Decentralization and its Contradictions in Uzbekistan. Central Asian Survey, 25 (4), $533-$ 549.

81. Oates, W.E., 1972. Fiscal Federalism. New York: Harcourt Brace Jovanovich.

82. Open Society Institute LGI, 2002. Local Government Situation and Development Prospects in the Countries of Central Asia. Regional Report on the Development of Local Self-Governments in Central Asia Countries.

83. Ostrom, E., Schroeder, L., and Wynne, S., 1993. Institutional incentives and sustainable development: infrastructure policies in perspective. Boulder, CO: Westview Press.

84. Paarmann, B., 2007. Evolving Centre-Periphery Relations in Transition Countries: The Case of Kazakhstan. MPhil Dissertation. University of Cambridge, Cambridge, UK.

85. Perlman, B.J. and Gleason, G., 2007. Cultural Determinism versus Administrative Logic: Asian Values and Administrative Reform in Kazakhstan and Uzbekistan. International Journal of Public Administration, 30 (12-14), 1327-1342.

86. Popa, V. and Munteanu, I., 2001. Local Government Reforms in the Former Soviet Union: Between Hope and Change. In: V. Popa and I. Munteanu, eds. Developing New Rules in the Old Environment. Local governments in Eastern Europe, in the Caucasus and in Central Asia. Budapest: Local Government and Public Service Reform Initiative, Open Society Institute Europe, 19-44.

87. Prud'Homme, R., 1995. The dangers of decentralization. The world bank research observer, 10 (2), 201-220.

88. Radnitz, S., 2005. Networks, localism and mobilization in Aksy, Kyrgyzstan. Central Asian Survey, 24 (4), 405-424.

89. Rasanayagam, J., 2011. Islam in Post-Soviet Uzbekistan: The Morality of Experience. Cambridge University Press.

90. Rodríguez-Pose, A. and Gill, N., 2003. Is there a global link between regional disparities and devolution? In: Research Papers in Environmental and Spatial Analysis No. 79, Department of Geography \& Environment, London School of Economics and Political Science.

91. Sahadeo, J. and Zanca, R., 2007. Everyday Life in Central Asia: Past and Present. Indiana University Press.

92. Saner, R., Toseva, G., Atamanov, A., Mogilevsky, R., and Sahov, A., 2008. Government Governance (GG) and Inter-Ministerial Policy Coordination (IMPC) in Eastern and Central Europe and Central Asia. Public Organization Review, 8 (3), 215-231.

93. Schatz, E., 2001. State Constructivism and Clans in Central Asia. Davis Center for Russian Studies, Harvard University.

94. Shahrani, M.N., 1995. Islam and the Political Culture of 'Scientific Atheism' in PostSoviet Central Asia: Future Predicaments. In: M. Bourdequx, ed. The Politics of Religion in Russia and New States The Politics of Religion in Russia and New States of Eurasia of Eurasia. Armonk, NY: ME Sharpe.

95. Shtaltovna, A., Hornidge, A.-K., and Mollinga, P.P., 2011. The reinvention of agricultural service organisations in Uzbekistan: A machine-tractor park in the Khorezm Region. ZEF Working Paper Series, No. 75. 
96. Siegle, J. and O’Mahoney, P., 2006. Assessing the Merits of Decentralization as a Conflict Mitigation Strategy. Washington D.C: paper prepared for USAID's Office of Democracy and Governance.

97. Sievers, E.W., 2002. Uzbekistan's Mahalla: from Soviet to Absolutist Residential Community Associations. The Journal of International and Comparative Law at Chicago-Kent, 2, 91-158.

98. Swartz, B., Wadsworth, F., and Wheat, J., 2011. Perceptions Of Corruption In Central Asian Countries. International Business \& Economics Research Journal (IBER), 7 (3).

99. Tiebout, C.M., 1956. A pure theory of local expenditures. The Journal of Political Economy, 64 (5), 416-424.

100.Trevisani, T., 2007. After the Kolkhoz: Rural Elites in Competition. Central Asian Survey, 26 (1), 85-104.

101.Tunçer-Kılavuz, İ., 2009. Political and social networks in Tajikistan and Uzbekistan: 'clan', region and beyond. Central Asian Survey, 28 (3), 323-334.

102.UNDP, 2014. UN Human Development Index [online]. UNDP Open Data. Available from:

https://data.undp.org/browse/embed?sortBy=alpha\&tags=hdi\&utf8=\%E2\%9C\%93\&view -type $=$ table \&page $=1$ [Accessed 4 Jun 2015].

103.Urinboyev, R., 2011a. Law, Social Norms and Welfare as Means of Public Administration: Case Study of Mahalla Institutions in Uzbekistan. The NISPAcee Journal of Public Administration and Policy, 4 (1), 33-57.

104.Urinboyev, R., 2011b. Bridging the State and Society: Case Study of Mahalla Institutions in Uzbekistan. In: Norms between Law and Society: A Collection of Essays from Doctoral Candidates from Different Academic Subjects and Different Parts of the World. Lund: Media-Tryck, Lund University, 115-133.

105.Urinboyev, R., 2013a. Living Law and Political Stability in Post-Soviet Central Asia. A Case Study of the Ferghana Valley in Uzbekistan. Ph.D. Dissertation, Lund Studies in Sociology of Law. Lund University, Lund.

106.Urinboyev, R., 2013b. Public Administration Developments in Post-Soviet Central Asia. In: M. Vintar, A. Rosenbaum, G. Jenei, and W. Drechsler, eds. The Past, Present and Future of Public Administration in Central and Eastern Europe. Bratislava: NISPAcee Press, 296-303.

107.Urinboyev, R., 2014. Is There an Islamic Public Administration Legacy in Post-Soviet Central Asia? An Ethnographic Study of Everyday Mahalla Life in Rural Ferghana, Uzbekistan. Administrative Culture, 15 (2), 35-57.

108.Urinboyev, R. and Svensson, M., 2013a. Corruption in a Culture of Money: Understanding Social Norms in Post-Soviet Uzbekistan. In: M. Baier, ed. Social and Legal Norms. Farnham: Ashgate, 267-284.

109.Urinboyev, R. and Svensson, M., 2013b. Living Law, Legal Pluralism, and Corruption in Post-Soviet Uzbekistan. The Journal of Legal Pluralism and Unofficial Law, 45 (3), 372 390.

110.Wanyande, P., 2004. Decentralization and Local Goverance: A Conceptual and Theoretical Discourse. Regional Development Dialogue, 25 (1), 1-13. 
111.Wiegmann, G., 2004. Local Alliances Providing Local Governance in Tajikistan? Working Paper.

112.Wilson, J., Gardner, D., Kurganbaeva, G., and Sakharchuk, E., 2002. The changing role of local government managers in a transitional economy. International Journal of Public Sector Management, 15 (5), 399-411.

\section{Rustamjon Urinboyev}

\section{Vietos valdžios gebėjimai posovietinèje Vidurio Azijoje}

\section{Anotacija}

Šiame straipsnyje analizuojama keturių Vidurio Azijos šalių - Kazachstano, Kirgizstano, Tadžikistano ir Uzbekistano - vietos valdymo kontekstas, problemos, kokybe ir iššūkiai. Daugiausiai dèmesio skiriama klausimui, ar veiksmingai ir našiai šiame regione vietos valdžia igyvendina savo funkcijas. Vietos valdžios institucijų gebejjimai analizuojami remiantis keturiais veiksniais - kontekstinėmis, struktūrinėmis, institucinėmis ir žmogiškujų išteklių sąlygomis. Šie klausimai analizuojami remiantis moksline literatūra ir viešosios politikos dokumentais. Tyrimo rezultatai rodo, jog vietos valdžios institucijos Vidurio Azijoje neturi reikiamų gebėjimų adekvačiai reaguoti i piliečių poreikius ir rūpesčius, nes jos yra stipriai priklausomos nuo centrinès valdžios visais viešosios politikos klausimais - ar tai būtų mokesčiai, paslaugų teikimas, vietos plètra ar privatizacija. Tyrimas taip pat rodo, jog vietos valdžios reforma šiame regione neturètų apsiriboti vien tiktai vakarietiškų valdymo struktūrų ịdiegimu ar didesnès autonomijos vietos institucijoms suteikimu. Daug svarbiau, kad būtų ìsigilinta ị vietos sociopolitinị kontekstą ir skatinami socioekonominiai pokyčiai.

Rustamjon Urinboyev - PhD student at the Department of Sociology of Law, Lund University.

E-mail: rustamjon.urindoyev@soclow.lu.se

Rustamjon Urinboyev - Lundo universiteto Teisès sociologijos katedros doktorantas. E.paštas: rustamjon.urindoyev@soclow.lu.se

Straipsnis įteiktas redakcijai 2015 m. rugpjūčio mèn.; recenzuotas; parengtas spaudai $2015 \mathrm{~m}$. rugsèjo mèn. 